\title{
Assessing facade value - how clients make business cases in changing real estate markets
}

\author{
Alexandra den Heijer* \\ Delft University of Technology (TU Delft), Faculty of Architecture and the Built Environment, \\ Department of Real Estate \& Housing, Delft, The Netherlands
}

Received: 23 July 2013

Accepted: 5 November 2013

\begin{abstract}
.
RELEVANCE: The value of any intervention in the built environment is most relevant for the stakeholders that are investing in it. For them all costs need to be balanced with benefits - not necessarily directly financial, but adding value to the performance of the accommodated organization. Business cases contain performance criteria like competitive advantage (branding the organization), productivity (optimally supporting users of the building), profitability (on organizational level) and sustainable development (monitoring the ecological footprint). In the changing real estate markets - from supply-driven to demand-driven and with increasingly higher vacancy rates - priorities in decisions about buildings have been shifting. PURPOSE: This paper elaborates on how (a) the trends in real estate markets and (b) changing priorities in decision making affect the quality demand for buildings and their facades.

DESIGN/METHODOLOGY/APPROACH: This paper is based on research of the Real Estate Management chair in general (market analysis, transformation trends, conceptual frameworks) and more specifically on decisions about university campuses in the past 10 years (14 campuses and 57 buildings assessed).

FINDINGS: This paper provides both conceptual frameworks to assess the (added) value of interventions in the built environment for the client and their (changing) priorities in the brief for buildings and their facades.
\end{abstract}

Keywords: Performance assessment, life cycle, costs, sustainable development, buildings, integration

\section{Introduction}

The value of any intervention in the built environment is most relevant for the stakeholders that are investing in it. For them all costs need to be balanced with benefits, not necessarily directly financial, but adding value to the performance of the accommodated organization or individuals. In general the 'return on investment' in the built environment is measured in better performance. The question is how to measure (changed) performance and relate it to choices in design and engineering, and more specifically - facades.

\footnotetext{
*Corresponding author: Dr. ir. Alexandra den Heijer, Delft University of Technology (TU Delft), Faculty of Architecture and the Built Environment, Department of Real Estate \& Housing, Julianalaan 134, 2628 BL Delft, The Netherlands. Tel.: +31 15 278 4159; E-mail: a.c.denheijer@tudelft.nl.
} 


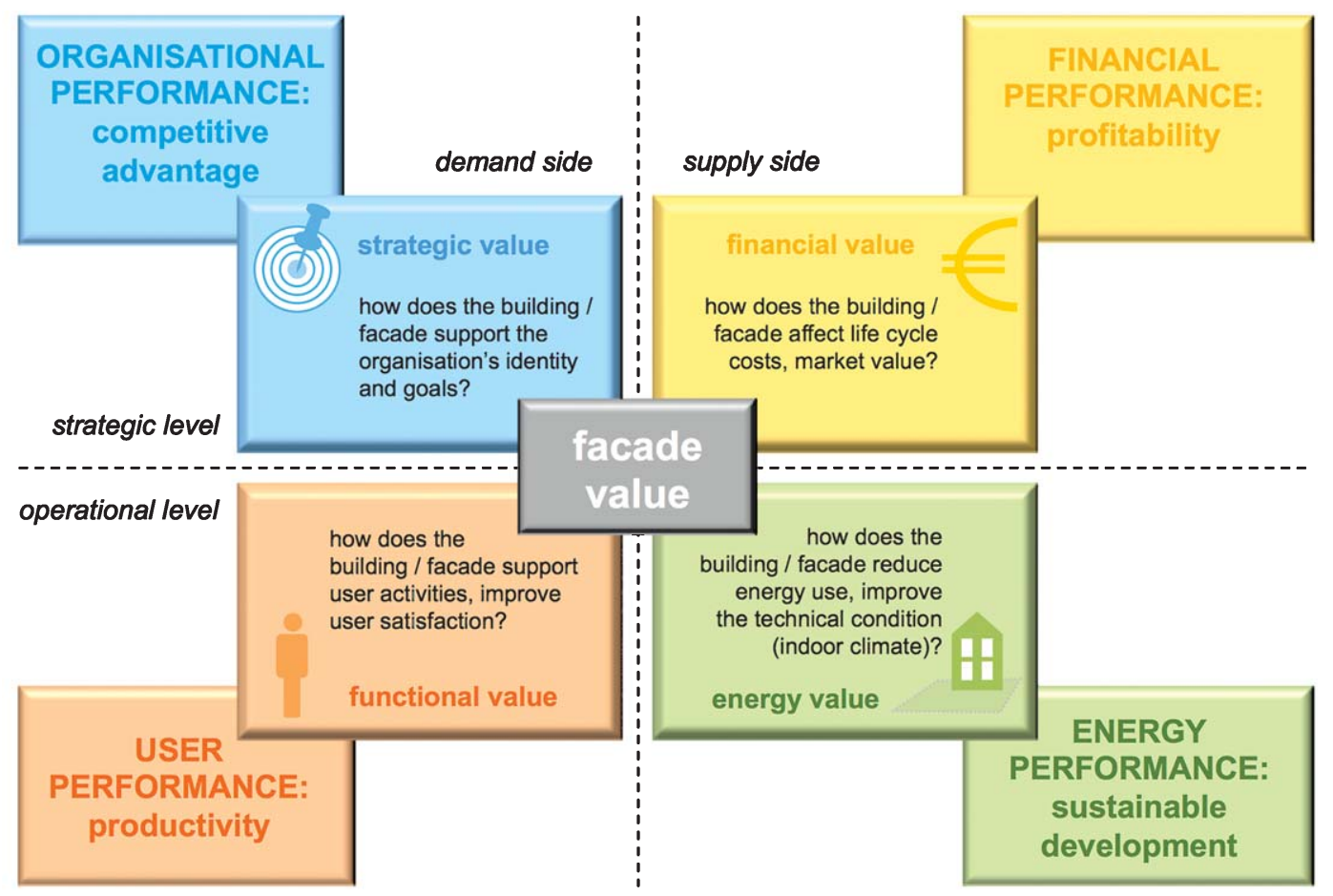

Fig. 1. Assessing 'facade value', linked to performance criteria (Den Heijer, 2011, edited).

\subsection{Scientific approach: Real estate management}

Measuring the (presumed) impact of real estate interventions on performance is the basis of 'real estate management' as a scientific discipline. If real estate had no effect on performance, no society, organisation or individual would spend resources on it. Ironically, it is easier to prove the negative effect of a dysfunctional facade on the productivity of employees - or image of an organisation than to find evidence for a positive effect on performance. However, any evidence of the effect on performance will be important to real estate managers, designers and engineers of the built environment of the future.

\subsection{Four types of values}

This paper focuses on decisions about (portfolios of) buildings and their (presumed) effect on performance, either negative or positive. It uses conceptual frameworks from corporate and public real estate management (De Vries, De Jonge \& Van der Voordt, 2008; Den Heijer, 2011) to operationalize 'facade value' linked to four performance criteria, see Fig. 1.

As illustrated in Fig. 1, there are four types of performance criteria that organisations are focussing on, based on empirical studies and interviews with decision makers in public and private organisations (De Vries et al., 2008; Den Heijer, 2011; Van der Schaaf, 2002). The four types of performance criteria connect demand side and supply side of the built environment, on strategic and operational level: competitive advantage (branding the organization), productivity (optimally supporting the users of 
the building), profitability (costs and benefits on organizational level) and sustainable development (monitoring the ecological footprint). These criteria correspond with four types of values: strategic, financial, functional and energy value. These values interact and need to be balanced in each decision about the built environment.

\subsection{Assessing four types of facade value}

In accordance with this theory the following four questions - corresponding with the four value types - should be answered when assessing 'facade value':

- How does the building's facade support the organisation's identity and goals, adding to the competitive advantage (rank, distinctiveness) of the organisation and representing the 'strategic value' of facades?

- How does the building/facade affect life cycle costs, market value, adding to the profitability (costs and benefits on organizational level) and representing the 'financial value' of facades?

- How does the building/facade support user activities, improve user satisfaction, adding to the productivity (output versus input) of the organisation and representing the 'functional value' of facades?

- How does the building/facade reduce energy use, improve the technical condition (indoor climate), adding to the sustainable development (reducing the ecological footprint) of the organisation and representing the 'energy value' of facades?

The strategic and functional value focus on (optimally supporting) the primary processes of the organisation - the demand side of the market; the financial and energy value focus on (reducing) the resources that are required for these processes - the supply side of the market. These four (facade) value types, the market changes that influence them (Section 2), the way they interact (Section 3), and how clients prioritize (Section 4) will be subject of this paper.

\subsection{Research methods and structure paper}

Research results from the Real Estate Management chair in general are used to describe the changing market context in Section 2: real estate market analysis in public and private sectors, trend reports and common real estate strategies. These results are based on document analysis, literature review and databases of buildings and their characteristics - location, age, functions, quality aspects (including the facade quality), costs and space utilization - making use of theories, concepts and conclusions from various PhD research projects (De Vries, De Jonge, \& Van der Voordt, 2008; Den Heijer, 2011; Remøy, 2010; Soeter, 2010).

In Sections 3 and 4 the different value types are operationalized and illustrated with evidence from $(\mathrm{PhD})$ research projects. Some conclusions about "user preferences" - aspects that users consider 'valuable' - and "priorities of decision makers" are based on either interviews or questionnaires (Remøy, 2010; Den Heijer, 2011). Next to analysing these stated preferences (and priorities) the revealed preferences were also assessed, collecting transaction and vacancy data, and relating preferences to rent prices and costs of ownership (functional versus financial aspects). For assessing decisions about university buildings all fourteen Dutch universities supplied project data (57 recent university projects) and portfolio data (14 university campuses). These databases are used to illustrate trends and to recognise patterns in decision making about buildings and their facades. This paper will 
end with conclusions and recommendations for both the design product (section 5) and the design process (Section 6).

\section{The changing market context}

Any decision about the built environment is influenced by developments and trends in the real estate market. This paper focuses on non-residential real estate. This market is currently (2013) characterised by high vacancy rates. This is illustrated with some figures from the Dutch real estate market: more than $14 \%$ - representing 7 to 8 million $\mathrm{m}^{2}$ - of commercial offices are vacant and more than $7 \%$ of commercial retail floor area, about 2 million $\mathrm{m}^{2}$. Both are likely to increase (rapidly) due to the on-going development of new office buildings and large-scale retail on the demand side and new ways of working and Internet shopping on the demand side (Heijnders, 2013; Koppels, Remøy, \& De Jonge, 2009; Remøy, 2010).

\subsection{Most real estate is not commercial}

However, 'commercial real estate' - even though it dominates the news about the real estate market - only represents a relatively small part of the total non-residential real estate portfolio. The majority of buildings are either 'corporate real estate' (owned and used by industry) or 'public real estate' (schools, hospitals, government buildings, cultural facilities). The Dutch non-residential real estate market consists of about $80 \mathrm{mln} \mathrm{m}^{2}$ commercial real estate (offices, retail - owned by private and institutional investors), $120-140 \mathrm{mln} \mathrm{m}^{2}$ 'public real estate' and more than $170 \mathrm{mln} \mathrm{m}^{2}$ 'corporate real estate' (Soeter, 2010; Heijnders, 2013). This excludes an estimated $250 \mathrm{mln} \mathrm{m}^{2}$ buildings for agricultural and other purposes (Soeter 2010, based on historical data about sectoral investment, building permits and demographic trends).

\subsection{Transformation as leading trend}

Since the economic crisis and the high vacancy rates 'transformation' has been the leading trend in the real estate market (Rem $\varnothing$ y \& Wilkinson, 2012), both in an 'upgrading' and 'downgrading' sense. Transformation usually refers to changing the function of the building - from office space to residential space for instance - in order to increase the profits per $\mathrm{m}^{2}$ (upgrading). Value is added when the profits exceed the costs per $\mathrm{m}^{2}$. This can also be achieved by choosing a function that will decrease the costs (downgrading). In any case the owner of the building will search for a function that is still in demand. Even the traditionally supply-driven market for 'commercial real estate' has become demand-driven, paying more attention to future use and users. Investors that have traditionally focussed on 'financial value' are now expanding their view to 'functional value', 'energy value' and 'strategic value', because their potential tenants have plenty of alternative choices.

\subsection{Vacancy is primarily related to location, but facade quality also matters}

Research (Koppels \& Remøy, 2013) shows that vacant buildings in the (commercial) office market are most likely located in mono-functional, peripheral areas. Certain 'age groups' are well represented in the vacancy rates, like buildings from the period 1980 to 1995 (Remøy, Koppels, \& De Jonge, 
2009). These buildings are more likely to be vacant because of their location than because of their building characteristics. Nonetheless, there also seems to be some evidence that the appearance of the building has an effect on structural vacancy. Facade material and the facade's technical quality are explicitly mentioned as aspects that matter when preventing vacancy or coping with vacancy (Remøy, 2010). Even for buildings that were built after 1995, poor facade quality significantly increases the odds of structural vacancy. Research results also illustrate that it is easier to prove the negative effect of a low quality facade than the positive effect of a high quality facade. However, these results show that facade quality matters in vacancy rates and that the facade therefore represents a financial value for real estate owners.

\subsection{User preferences: The building's appearance is important}

Apart from assessing vacancy rates - identifying revealed preferences of office users - there are also research projects that measure 'stated preferences': how office users themselves rank their preferences (which can differ from revealed preferences due to the effect of price). Next to location aspects like the availability of parking, the appearance of the building and the space efficiency (flexible lay-out) had the highest scores in a so-called 'office scan' (Remøy et al., 2009; Remøy, 2010). The researchers stated that in times of crisis office tenants are "keeping up appearances", referring to the importance of the building's exterior. The building's appearance was studied as several separate variables, including facade material, specific architecture, monumentality and building height. Other research that compares the Dutch and the Australian office market, shows that - in adaptation projects - changing the appearance of the building has a relatively high added value compared to other interventions (Wilkinson \& Remøy, 2011). This last conclusion again emphasizes the financial value of facades (extra investment in the facade versus added value per $\mathrm{m}^{2}$ ).

\subsection{Energy performance also affects vacancy}

Because of the increased attention for sustainable development - there is a relation between vacancy and building characteristics for buildings dated from 1995 (until 2013). Their energy performance plays a role in the vacancy rates: a better the energy performance is more attractive for tenants and consequently also leads to more cash flow. This relation illustrates the connections between 'energy value' on the one hand and 'functional value' and 'financial value' on the other hand. Since the facade plays an important role in the energy performance of buildings, this highlights the energy value of the facade and - due to its impact on both productivity and vacancy - indirectly the functional and financial value of the facade.

\subsection{Demand-driven markets}

Corporate and public real estate markets are much more 'demand-driven' than commercial real estate markets: their focus is on their primary processes (i.e. selling products, education, health care). Real estate is just one of the resources to achieve the corporate or public goals. Consequently, they will compare the effectiveness of an investment in their buildings with an investment in their personnel (Den Heijer \& De Jonge, 2012). Owners of these buildings want to measure the effect of a new facade on their performance (productivity, rank, profit, footprint). If a smart facade can improve 
their productivity with $5 \%$, this can be worth extra investments, which should be made explicit in a business case.

For owners and users of 'corporate real estate' and 'public real estate' assessing the influence of the building on performance has a longer history. Their accountability to stakeholders or responsibility to achieve political goals forced them to. Consequently, they are more likely to make business cases when they assess the (added) value of investments in their buildings. Compared to commercial real estate owners they will put more emphasis on energy value, functional value and strategic value than on (only) financial value - also when assessing the added value of the facade.

\subsection{Decentralised budgets}

If one trend characterises the context of public real estate, it is the tendency to decentralise budgets to the users themselves (boards of schools, universities, hospitals, etc.). The advantage is that all performance criteria - strategic, financial, functional and physical (energy) - are covered by the same organisation, overseeing both the investment costs and the operating costs. The disadvantage is that the organisation needs expertise on all of these subjects to make 'the right decision about a project' by weighing different types of values. Since this is even a complex matter to experts, this challenge can also lead to suboptimal decisions, like choosing a facade based only on the (lowest) initial costs. Consultants, designers and engineers can support clients in the decision-making process by including all value types in their arguments for building (facade) solutions.

\subsection{Decreasing budgets}

In the past decades the decentralisation of budgets has usually been combined with 'budget cuts', which has forced organisations to be more efficient with their resources. This could lead to focussing on the lowest initial investment level (of a construction project), even if it doubles the operating costs or - worse - negatively affects their productivity. Nonetheless, the culture of assessing 'life cycle costs' and measuring the effect on performance has become more common. This is most established in sectors with large 'public real estate' portfolios, like government buildings (9-12 $\mathrm{mln} \mathrm{m}^{2}$ in Netherlands), schools and universities $\left(40-45 \mathrm{mln} \mathrm{m}^{2}\right)$ and health care facilities (roughly $55 \mathrm{mln} \mathrm{m}^{2}$ ), data (Heijnders, 2013) from EIB and VNG. These are the types of clients that are most likely to make business cases for their decisions about transforming, adapting or adding buildings - to account for spending public resources and to demonstrate the added value to public goals.

\subsection{Strategy: More quality and less quantity}

As a consequence of market developments current trends in corporate and public real estate are reducing the footprint (both ecological and physical: in $\mathrm{m}^{2}$ ), considering transformation before adding new space, reconsidering 'territory' and encouraging 'shared space' (Den Heijer, 2011). This can be summarized in "trading quantity for quality of space" (less $\mathrm{m}^{2}$, higher quality). Still, higher costs per $\mathrm{m}^{2}$ need to be compensated by higher benefits per $\mathrm{m}^{2}$. These trends in the (public) sectors are illustrated in the next sections, using university real estate as an example. 


\section{Assessing value - financial versus functional value}

When assessing design and construction projects many clients still consider the investment costs the most important part of 'financial value'. Fig. 2 shows a selection of Dutch campus projects (57 projects in the database, Den Heijer, 2011; Den Heijer, Curvelo Magdaniel \& Bentinck, 2013) in $\mathrm{m}^{2}$, investment level, use and goals. These projects were described to create references for new campus projects. The investment levels of these projects range from 1375 to 4160 euros per $\mathrm{m}^{2}$ gross floor area (gfa). The database also includes operating costs (maintenance, energy and cleaning), which are equally important as investment costs for assessing financial value.

\subsection{Focus on life cycle costs}

Increasingly, clients are focussing on life cycle costs: the total costs of ownership (or rent) per $\mathrm{m}^{2}$. For the total campus these range from 70 to 130 euro per $\mathrm{m}^{2}$ gfa (data from 13 Dutch universities, Den Heijer, 2011). Case study research of school buildings also showed that the annual operating costs have a larger share in the life cycle costs than the annual capital costs of the initial investment in the building (De Jong \& Arkesteijn 2013). The annual capital costs are influenced by what is considered the economic lifetime of an investment -30 years is considered a standard depreciation period. A building with an investment level of $3000 € / \mathrm{m}^{2}$ would roughly have annual capital costs of $100 € / \mathrm{m}^{2}$, when not considering interest on the loan. However, components of the building could have a longer or shorter functionality, which could lead to new investments (replacements) after 15 years. Any (facade) solution that extends the functional lifetime and postpones reinvestments can be worth its initial (extra) investment, which life cycle costs calculations could indicate.

\subsection{Measuring benefits per $m^{2}$}

In the annual operating costs the three larges components are 'maintenance', 'energy' and 'cleaning' costs. Especially energy costs are increasing rapidly (Estate Management Statistics, AUDE, United Kingdom). In the UK more than 160 universities compare data about property costs (75 to $100 \mathrm{f} / \mathrm{m}^{2}$ $\mathrm{m}^{2}$ net internal area (NIA) for the whole campus, excluding capital costs). At the same time UK universities collect data about the benefits per $\mathrm{m}^{2}$. They use key performance indicators (KPIs) like "teaching income per $\mathrm{m}^{2}$ teaching space" and "research income per $\mathrm{m}^{2}$ research space". In the same year teaching income ranged from 1400 to $2100 \mathrm{f} / \mathrm{m}^{2}$ NIA and research income from 1100 to 2300 $\mathrm{f} / \mathrm{m}^{2}$ NIA. If an investment in a new facade concept could add $5 \%$ to the productivity (leading to profit) per $\mathrm{m}^{2}$ annually, the extra capital costs per $\mathrm{m}^{2}$ could be $55 \mathrm{f} / \mathrm{m}^{2} \mathrm{NIA}$ (considering the lowest income $/ \mathrm{m}^{2}$ ). This can be capitalized to an investment budget. This is the type of business case clients should make for any design, construction or management decision.

\subsection{Functional value: Hierarchy of needs}

The example above shows that financial value is very much dependent on functionality. Functional value and financial value are closely connected, representing the benefits and costs of a project. For assessing the functional value Maslov's hierarchy of needs (1954) can be used as a conceptual framework. This classification of cumulative human needs is a useful tool for determining perceptual qualities that need to be realised and should be operationalized in the brief for a building (Blyth \& 


\begin{tabular}{|c|c|c|c|c|c|c|}
\hline & & $\begin{array}{c}\text { code } \\
\text { city / university } \\
\text { project }\end{array}$ & $\begin{array}{l}\text { UM-3 } \\
\text { Maastricht / LEI } \\
\text { University College }\end{array}$ & $\begin{array}{c}\text { EUR-2 } \\
\text { Delft / TUD } \\
\text { BK city (Architecture) }\end{array}$ & $\begin{array}{c}\text { EUR-2 } \\
\text { Rotterdam / EUR } \\
\text { T building }\end{array}$ & $\begin{array}{c}\text { TUE-5 } \\
\text { Eindhoven/ TUE } \\
\text { Metaforum }\end{array}$ \\
\hline & & $\begin{array}{c}\text { project type } \\
\text { completion year }\end{array}$ & $\begin{array}{c}\text { renovation } \\
2006\end{array}$ & $\begin{array}{c}\text { new + renovation } \\
2009\end{array}$ & $\begin{array}{c}\text { new building } \\
2005\end{array}$ & $\begin{array}{c}\text { new + renovation } \\
2012\end{array}$ \\
\hline $\mathrm{M}^{2}$ & ‥t & $m^{2} g f a(b v o)$ & 4.800 & 36.000 & 46.100 & 26.900 \\
\hline USE & & $\begin{array}{c}\text { workplace- } m^{2} \text { ufa (no) } \\
\text { office-\% } \\
\text { education-\% } \\
\text { specific- } \%\end{array}$ & $\begin{array}{c}\mathbf{1 3 , 3} / \text { fte } \\
15 \% \\
77 \%\end{array}$ & $\begin{array}{c}11,6 / \text { fte } \\
65 \% \\
17 \% \\
2 \% \\
\end{array}$ & $\begin{array}{c}17,1 / \text { person } \\
65 \% \\
17 \% \\
2 \% \\
\end{array}$ & $\begin{array}{c}17,0 / \text { fte } \\
49 \% \\
49 \%\end{array}$ \\
\hline$€$ & & $\begin{array}{l}\text { investment } \epsilon \text { (million) } \\
\text { investment } \epsilon / m^{2} \text { gfa }\end{array}$ & $\begin{array}{c}€ 6,6 \\
€ 1.375\end{array}$ & $\begin{aligned} & € 50 \\
& € 1.400\end{aligned}$ & $\begin{array}{r}€ 72,5 \\
€ 1.570\end{array}$ & $\begin{array}{r}€ 51,0 \\
€ 1.900\end{array}$ \\
\hline GOALS & & $\begin{array}{c}\text { representative } \\
\text { meeting place } \\
\text { plain \& efficient }\end{array}$ & $\begin{array}{l}\text { representative } \\
\text { moeting place } \\
\text { pláin \& efficient }\end{array}$ & $\begin{array}{l}\text { representative } \\
\text { moleting pláce } \\
\text { pjáin \& efficięnt }\end{array}$ & $\begin{array}{l}\text { móting place } \\
\text { pyáin \& efficiènt }\end{array}$ & $\begin{array}{l}\text { mesting place } \\
\text { plafin \& efficièt }\end{array}$ \\
\hline
\end{tabular}

\begin{tabular}{|c|c|c|c|c|c|c|}
\hline & & $\begin{array}{c}\text { code } \\
\text { city / university } \\
\text { project }\end{array}$ & $\begin{array}{c}\text { RUG-7 } \\
\text { Groningen / RUG } \\
\text { Eriba (research institute) }\end{array}$ & $\begin{array}{c}\text { LEI-2 } \\
\text { Leiden / LEI } \\
\text { Kamerlingh Onnes }\end{array}$ & $\begin{array}{c}\text { UT-4 } \\
\text { Twente / UT } \\
\text { Carré (faculty science) }\end{array}$ & $\begin{array}{c}\text { RU-2 } \\
\text { Nijmegen / RU } \\
\text { Huygens (faculty NWI) }\end{array}$ \\
\hline & & $\begin{array}{c}\text { project type } \\
\text { completion year }\end{array}$ & $\begin{array}{c}\text { new building } \\
2012\end{array}$ & $\begin{array}{c}\text { new + renovation } \\
2004\end{array}$ & $\begin{array}{c}\text { new building (science) } \\
2009\end{array}$ & $\begin{array}{c}\text { new building (science) } \\
2006 \\
\end{array}$ \\
\hline $\mathrm{M}^{2}$ & . & $m^{2} g f a(b v o)$ & 5.760 & 20.500 & 35.410 & 50.100 \\
\hline USE & & $\begin{array}{c}\text { workplace- } m^{2} \text { ufa (no) } \\
\text { office- } \% \\
\text { education-\% } \\
\text { specific- } \%\end{array}$ & no office data & $\begin{array}{c}15,9 / \text { fte } \\
38 \% \\
19 \%\end{array}$ & $\begin{array}{c}22,5 / \text { fte } \\
43 \% \\
14 \% \\
58 \% \\
\end{array}$ & $\begin{array}{c}13,6 / \text { fte } \\
41 \% \\
13 \% \\
22 \% \\
\end{array}$ \\
\hline$\varepsilon$ & & $\begin{array}{l}\text { investment } \epsilon \text { (million) } \\
\text { investment } \epsilon / m^{2} \text { gfo }\end{array}$ & $\begin{array}{l}€ 15,1 \\
€ 2.620\end{array}$ & $\begin{array}{r}€ 59,8 \\
€ 2.630\end{array}$ & $\begin{array}{r}€ 93,8 \\
€ 2.650\end{array}$ & $\begin{array}{l}€ 132,8 \\
€ 2.650\end{array}$ \\
\hline GOALS & & $\begin{array}{l}\text { representative } \\
\text { meeting place } \\
\text { plain \& efficient }\end{array}$ & medting phace & $\begin{array}{l}\text { repressentative } \\
\text { moéting phace } \\
\text { pyáin \& efficiènt }\end{array}$ & $\begin{array}{l}\text { mgéting phace } \\
\text { pjáin \& efficient }\end{array}$ & pyafin \& efficiènt \\
\hline
\end{tabular}

Fig. 2a. A selection of Dutch campus projects, expressed in $\mathrm{m}^{2}$, euros, use and goals - codes refer to the project database - price level 2009 or 2012 (for projects after 2009), workplace- $\mathrm{m}^{2}$ and \% refer to usable floor area (ufa), investment costs are related to gross floor area (gfa) - for full project profiles, see dissertation (Den Heijer, 2011) and benchmark report (Den Heijer et al., 2013): http://managingtheuniversitycampus.nl/publications. 


\begin{tabular}{|c|c|c|c|c|c|c|}
\hline & & $\begin{array}{c}\text { code } \\
\text { city/university } \\
\text { project }\end{array}$ & $\begin{array}{c}\text { VU-1 } \\
\text { Amsterdam / VU } \\
\text { OZW building }\end{array}$ & $\begin{array}{c}\text { WU-3 } \\
\text { Wageningen / WU } \\
\text { Forum (BSc building) }\end{array}$ & $\begin{array}{c}\text { RUG-4 } \\
\text { Groningen / RUG } \\
\text { Bernoulliborg }\end{array}$ & $\begin{array}{c}\text { UvA-4 } \\
\text { Amsterdam / UvA+VU } \\
\text { University College }\end{array}$ \\
\hline & & $\begin{array}{c}\text { project type } \\
\text { completion year }\end{array}$ & $\begin{array}{c}\text { new building } \\
2006\end{array}$ & $\begin{array}{c}\text { new building } \\
2007\end{array}$ & $\begin{array}{c}\text { new building } \\
2007\end{array}$ & $\begin{array}{c}\text { new building } \\
2012\end{array}$ \\
\hline $\mathrm{M}^{2}$ & 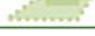 & $m^{2} g f a(b v o)$ & 20.100 & 35.300 & 12.000 & 5.820 \\
\hline USE & & $\begin{array}{c}\text { workplace- } m^{2} \text { ufa (no) } \\
\text { office- } \% \\
\text { education-\% } \\
\text { specific- } \%\end{array}$ & $\begin{array}{c}12,8 / \mathrm{fte} \\
21 \% \\
52 \% \\
4 \%\end{array}$ & $\begin{array}{c}28,7 / \mathrm{fte} \\
13 \% \\
39 \% \\
4 \%\end{array}$ & $\begin{array}{c}20,4 / \mathrm{fte} \\
49 \% \\
21 \% \\
2 \%\end{array}$ & $\begin{array}{c}14,3 / \text { fte } \\
19 \% \\
35 \%\end{array}$ \\
\hline$€$ & & $\begin{array}{l}\text { investment } \varepsilon \text { (million) } \\
\text { investment } € / m^{2} \text { gfa }\end{array}$ & $\begin{array}{l}€ 39,8 \\
€ 1.980\end{array}$ & $\begin{array}{r}€ 75,9 \\
€ 2.150\end{array}$ & $\begin{array}{r}€ 26,5 \\
€ 2.210\end{array}$ & $\begin{array}{r}€ 13,6 \\
€ 2.340\end{array}$ \\
\hline GOALS & & $\begin{array}{l}\text { representative } \\
\text { meeting place } \\
\text { plain \& efficient }\end{array}$ & $\begin{array}{l}\text { representative } \\
\text { meeting place } \\
\text { pjáin \& efficiènt }\end{array}$ & $\begin{array}{l}\text { representative } \\
\text { moeting plance } \\
\text { pjáin \& efficiènt }\end{array}$ & $\begin{array}{l}\text { representative } \\
\text { moeting phince } \\
\text { pjáin \& efficient }\end{array}$ & $\begin{array}{l}\text { representative } \\
\text { moeting place } \\
\text { pyáin \& efficient }\end{array}$ \\
\hline
\end{tabular}

\begin{tabular}{|c|c|c|c|c|c|c|}
\hline & & $\begin{array}{c}\text { code } \\
\text { city/university } \\
\text { project }\end{array}$ & $\begin{array}{c}\text { UvA-2 } \\
\text { Amsterdam / UvA } \\
\text { FNWI (faculty science) }\end{array}$ & $\begin{array}{c}\text { VU-3 } \\
\text { Amsterdam / VU } \\
\text { ACTA (dentistry) }\end{array}$ & $\begin{array}{c}\text { LEl-4 } \\
\text { Leiden / LEI } \\
\text { Sterrewacht }\end{array}$ & $\begin{array}{c}\text { UU-3 } \\
\text { Utrecht/ UU } \\
\text { Jeanette Donker-Voet }\end{array}$ \\
\hline & & $\begin{array}{c}\text { project type } \\
\text { completion year }\end{array}$ & $\begin{array}{c}\text { new + renovation } \\
2010\end{array}$ & $\begin{array}{c}\text { new building (medical) } \\
2009\end{array}$ & $\begin{array}{l}\text { restoration } \\
2012\end{array}$ & $\begin{array}{c}\text { new building (lab) } \\
2006\end{array}$ \\
\hline$M^{2}$ & & $m^{2} g f a(b v o)$ & 70.320 & 25.100 & 4.480 & 6.300 \\
\hline USE & & $\begin{array}{c}\text { workplace- } m^{2} \text { ufa (no) } \\
\text { office- } \% \\
\text { education- } \% \\
\text { specific- } \%\end{array}$ & $\begin{array}{c}11,5 / f t e \\
28 \% \\
14 \% \\
35 \% \\
\end{array}$ & $\begin{array}{c}10,7 / \mathrm{fte} \\
18 \% \\
17 \% \\
27 \% \\
\end{array}$ & $\begin{array}{c}34,2 \text { / person } \\
24 \% \\
29 \%\end{array}$ & $\begin{array}{c}6,4 / \text { person } \\
24 \% \\
3 \% \\
45 \% \\
\end{array}$ \\
\hline$\varepsilon$ & & $\begin{array}{l}\text { investment } € \text { (million) } \\
\text { investment } € / m^{2} \text { gfa }\end{array}$ & $\begin{array}{l}€ 186,3 \\
€ 2.650\end{array}$ & $\begin{array}{r}€ 75,7 \\
€ 3.020 \\
\end{array}$ & $\begin{array}{r}€ 14,7 \\
€ 3.280\end{array}$ & $\begin{array}{c}€ 26,2 \\
€ 4.160\end{array}$ \\
\hline GOALS & & $\begin{array}{l}\text { representative } \\
\text { meeting place } \\
\text { plain \& efficient }\end{array}$ & pyáin \& efficiènt & $\begin{array}{l}\text { representative } \\
\text { moeting place } \\
\text { pláin \& efficient }\end{array}$ & $\begin{array}{l}\text { representative } \\
\text { moleting place } \\
\text { prain \& efficient }\end{array}$ & pjáin \& e \\
\hline
\end{tabular}

Fig. 2b. (Continued) 


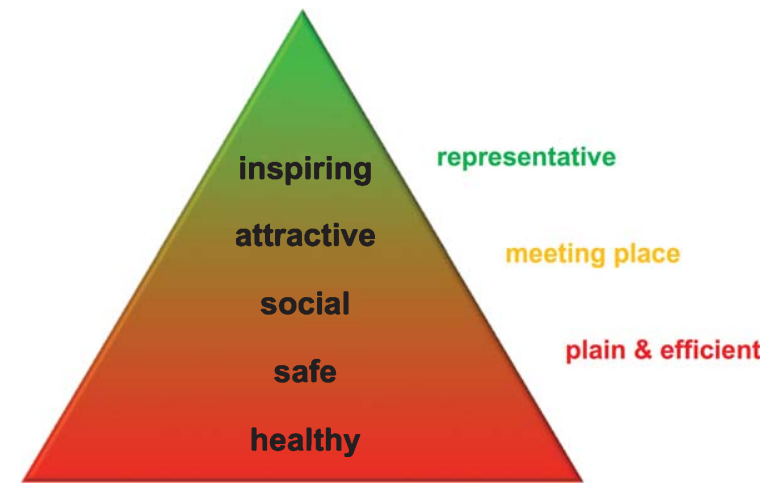

Fig. 3. Hierarchy of needs - cumulative levels in quality demand, used for campus research: goals of projects: "plain \& efficient" (covering healthy \& safe), "meeting place" (adding social) and "representative" (adding attractive and inspiring) applied in Fig. 2.

Worthington 2001). Maslov defined seven types of needs: (a) physiological needs, (b) safety needs, (c) social needs: need for contact, (d) esteem needs, to be valued and respected, (e) cognitive need: the urge to know and understand, (f) aesthetic needs: striving towards beauty and the perception thereof and $(\mathrm{g})$ self-actualisation. For the brief of buildings these were translated to cumulative quality levels for creating a healthy, safe, social, attractive and inspiring built environment, see Fig. 3 .

The essence of these cumulative needs is that they need to be fulfilled from bottom to top: just investing in an attractive physical environment without covering health \& safety issues can have an adverse effect on both production and user satisfaction. In practice many campus managers have discovered that creating a (social) place to meet has been more functional - leading to more productivity - than creating a 'landmark building'. This aligns with Maslov's theory. A landmark building usually adds to strategic value - adding to the reputation and attractiveness of the organisation. Investing in (facade) aesthetics is also used for urban regeneration, adding to the reputation or image of an urban area (Riccardo, Van Oel, \& De Jong, 2012).

Other research shows that investing in a healthy and safe environment has the best measurable effect on productivity (i.e. TNO, 2007: assessing school buildings). Again, finding evidence for the negative effect of an unhealthy indoor environment on productivity is much easier. Business cases for new (facade) concepts - especially when assessing transformation projects - could also aim at 'preventing future productivity loss', as another way of 'increasing productivity'. Sustainable innovations can contribute to healthier and safer indoor environment, while contributing to sustainability goals at the same time. The energy performance of the built environment has gained importance in the past decade: many organisations have signed agreements to reduce the footprint, not just the ecological footprint, but also the physical footprint - in floor area per user (Den Heijer \& Teeuw, 2011). Priorities of policy makers have changed, influenced by market developments and changed needs of society, organisations and user groups. More emphasis on better use of scarce resources (energy, euros, $\mathrm{m}^{2}$ ) has changed the real estate strategies of many clients, which will be illustrated in the next section.

\section{Changing priorities of decision makers - strategies to reduce footprint}

Interviews with decision makers about campuses in the past five years illustrated a change in strategy: from creating territory to creating shared space. The (very) low occupancy rates of classrooms, 
lecture halls, laboratories and offices in combination with the high life cycle costs per $\mathrm{m}^{2}$ were the main incentive. The relative large footprint per student and academic staff member also negatively affected the benefits per $\mathrm{m}^{2}$ : the production in terms of diplomas, publications, citations, patents etc. Increasing flexibility while safeguarding identities of user groups has become the challenge on campus - balancing energy use and strategic value.

\subsection{Key performance indicators to measure effect}

Reducing the footprint as a campus strategy has many positive effects on a university's performance: it could reduce the costs, increase the benefits per $\mathrm{m}^{2}$, encourage social and intellectual interaction between different user groups and add to sustainability goals. To measure these effects (before and after the project) key performance indicators are used for sustainable development (from $\mathrm{CO}_{2}$ omission to $\mathrm{m}^{2}$ per student), for productivity (occupancy rates, user satisfaction), profitability (life cycle costs as \% of income per $\mathrm{m}^{2}$ ) and competitive advantage (importance of quality of life and facilities in the university's reputation monitor). To illustrate the impact of facilities on competitive advantage: "In 2011 research showed that 36\% of British students rejected a university due to the (poor) quality of its estate" (HEDQF, 2012). Strategic value is usually expressed in terms of 'opportunity costs': the cost of an alternative strategy to achieve the same goal. The campus projects that were introduced in Fig. 2 will be assessed over time on these key performance indicators: are the project goals achieved and what can designers and other decision makers learn from that assessment?

By analysing projects from many different public and private portfolios evidence is collected about the (added) strategic, functional, financial and energy value of (facade) solutions, which will support designers and engineers. Based on evidence-based insights they can improve their products, aligning with the client's demands in the (facade) brief. It will also contribute to better communication between the client, designers and engineers, while the key performance indicators combine variables from both the demand side (goals, users, needs) and the supply side ( $\mathrm{m}^{2}$, quality, costs, energy use).

\section{Conclusions and recommendations - propositions for the (facade) brief}

Summarizing the previous sections, the following question should be answered to assess 'facade value': how does the facade influence the organization's productivity, profit, identity and sustainability goals? This paper gave an overview of research projects that contribute to answering this comprehensive research question. Notions from real estate management research can help to find more evidence-based answers to this question, to support facade designers and engineers in understanding the preferences and decision-making process of clients. Some of them are expressed below, in conclusions about facade value and recommendations for the (facade) brief.

- The facade brief should contain aspects that refer to all value types: financial value, energy value, functional value and strategic value. Consultants, designers and engineers can support clients in the decision-making process by including all value types in their arguments for building (facade) solutions. 


\subsection{Financial facade value}

- Arguments about how the facade adds to financial value should relate the initial investment costs to the annual capital costs (depending on the lifetime of the solution: the period until reinvestment is required) and the operating costs, demonstrating a life cycle costs approach. At the same time, these life cycle costs should be compared to life cycle benefits (production per $\mathrm{m}^{2}$ ).

- Architects and engineers should find solutions to extend the functional lifetime of their concepts, because this will add to the benefits per $\mathrm{m}^{2}$, decrease the annual capital costs per $\mathrm{m}^{2}$ and enable a higher initial investment level (larger budget for the project).

- To increase profitability it can be a better strategy to improve space utilization and reduce floor area than to save costs on the quality of the building and its facade.

\subsection{Functional facade value}

- Arguments about how the facade adds to functional value should include the influence of the facade on productivity - or on preventing productivity loss - and how the facade supports the changing user needs.

- Useful in the facade brief can be the notions from Maslov's theory, a cumulative approach to user needs: health, safety, social and aesthetic needs (in that order). Focussing on aesthetics before focussing on health and safety issues negatively influences user satisfaction and functional value. Even fulfilling social needs - like adding to the sense of community - precedes satisfying aesthetic needs, according to Maslov's hierarchy of needs. Increasingly, organisations want to be open and transparent, show the production process and enable (social) interaction to encourage innovation - facade design should support this ambition.

- With the increasingly shorter functional lifetimes of buildings - due to rapidly changing user needs and changing tenants of buildings - flexibility is an important strategy, because many buildings will be adapted or transformed during their lifetime. Since the use of the building has to be flexible, the facade should not dictate fixed solutions for the floor plan. This also relates to the flexible floor plan as one of the highest-scoring user preferences.

\subsection{Energy facade value}

- Arguments about how the facade adds to energy value should include the influence of the facade on the indoor environment and energy use.

- Related to (reducing) the energy value and adding to sustainability goals many clients are changing their strategies to 'reducing their footprint' and shared space, even though identity of users has become more import. Trading quantity of space for quality of space (which adds to the identity of users) has become a popular strategy. In short: more focus on reducing the client's footprint will save resources to invest in quality of space.

\subsection{Strategic facade value}

- Arguments about how the facade adds to strategic value should refer to the image of the organisation and how its most important stakeholders (and clients) perceive the quality. For some types 
of organisations a facade with a high aesthetic quality (implying relatively high initial costs) can even have a negative affect on the organisation's image.

- Strategic value for commercial real estate owners can also be related to the long-term rentability of the building, preventing vacancy. Research shows that the quality of the facade does have an impact on office vacancy rates and is ranked in the top 3 of user preferences. These research results show that facade quality matters in vacancy rates and that the facade therefore represents a financial value for real estate owners.

- In general it is recommended to relate every design decision to the client's performance criteria. That includes the process of defining the (facade) brief, in close collaboration with the client. This approach will also contribute to better communication between clients and designers.

\section{New partnerships in the design process}

Many conclusions and recommendations as stated above are subject of on-going research to collect more evidence and customised business cases to support them or elaborate upon them. Project databases - like the campus databases - can be used to generate references to support design decisions. This requires data from both supply and demand side of the project. This encourages partnerships between designers and clients at an early stage, to improve so-called 'value chains'.

Involving the client - the future owner/user of the building - in briefing and design decisions is one step, but giving them the evidence-based knowledge about how new (facade) concepts influence their performance is even more important for successfully implementing innovation in the built environment.

For the future of the built environment demand and supply side should go hand-in-hand. Research that explores the changing roles of designers also emphasizes that. This is all the more reason to share knowledge between the chairs of Real Estate Management, Design \& Construction Management and Design of Constructions for future research. This paper can be considered as a first step in making this happen.

\section{Acknowledgments}

The author wants to thank the staff of the Facade Research Group at the Faculty of Architecture and the Built Environment of the TU Delft for the opportunity to approach this subject from a different scientific perspective, both at the Future Envelope 7 "Facade Value" conference in June 2013 and in this paper. This is considered to be the starting point of more collective projects, which I look forward to. I want to thank my colleagues at the department of Real Estate \& Housing for providing their most relevant research material, which could be merged into a comprehensive overview of the knowledge that we could share on this subject, to improve the communication between client and designers/engineers - spending the scarce resources on the most effective interventions - and to collectively contribute to the quality of the built environment.

\section{References}

Blyth, A., \& Worthington, J. (2001). Managing the brief - for better design, London, Spon Press [using Maslov 1954 - hierarchy of needs]. De Jong, P., \& Arkesteijn, M. (2013). "Life Cycle Costs of Dutch school buildings", conference paper, ERES 2013, Vienna. 
De Vries, J. C., De Jonge, H., \& Van der Voordt, T. (2008). "Impact of real estate interventions on organisational performance", in Journal of Corporate Real Estate, Vol. 10.

Den Heijer, A. (2011). Managing the university campus - Information to support real estate decisions, (dissertation/book), Delft, Eburon Academic Publishers.

Den Heijer, A., \& Teeuw, P. (2011). "Sustainable visions for the campus of the future", at MISBE 2011, Management and Innovation for a Sustainable Built Environment, Amsterdam, The Netherlands.

Den Heijer, A. \& De Jonge, H. (2012). "Adding value - linking decisions and performance” in P. A., Jensen, T., Van der Voordt, \& C. Coenen, (eds.), FM Added Value Anthology, Lyngby (Denmark): Polyteknisk.

Den Heijer, A., Curvelo Magdaniel, F. \& Bentinck, S. (2013). Dutch university campus projects (part 4:17 projects) - HOI Benchmark 2012-2013, (research report for 14 Dutch universities). Delft: TU Delft.

"Estate Management Statistics" (2010). Association of University Directors of Estates (AUDE), retrieved through AUDE website http://aude.ac.uk (directly: http://www.hesa.ac.uk).

Heijnders, L. (2013). Vastgoed - problematiek en oplossingsrichtingen (report for The Social and Economic Council of the Netherlands SER - in Dutch: Sociaal-Economische Raad), Rijksgebouwendienst/TU Delft, 2013.

HEDQF (2012). "Higher educational facilities research" report by Higher Education Design Quality Forum, HEDQF, UK (google: "Out of the Box" AUDE 2012).

Koppels, P., \& Hilde R. (2013, forthcoming). “The Amsterdam office market, (dataset, maps and preliminary conclusions)" - to be published in 2013, client: Municipality of Amsterdam.

Koppels, P. W., Remøy, H. T., \& de Jonge, H. (2009). "The economic value of image" in PropertyNL Research Quarterly, 31-38.

"Performance in higher education estates"(2006) by Association of University Directors of Estate (AUDE) - Estate Management Statistics (EMS), annual report.

Remøy, H., Koppels, P., \& De Jonge, H. (2009). "Keeping up Appearance" in Real Estate Research Quarterly, 8(3).

Remøy, H. (2010). Out of Office - a study on the cause of office vacancy and transformation as a means to cope and prevent. PhD thesis, TU Delft, Faculty of Architecture.

Remøy, H. T., \& Wilkinson, S. J. (2012). Office building conversion and sustainable adaptation: A comparative study, Property Management, 30(3), 218-231.

Riccardo, F., Van Oel, C. J., \& De Jong, P. (2012). “Neighbourhood regeneration by facade redesign: A visual experiment on energy efficiency and aesthetics." in The International Journal of Architectonic, Spatial, and Environmental Design, 6(2), 57-80.

Soeter, J. P. (2010). Bouw- en voorraadeconomie 1960-2025, Delft, VSSD.

TNO, Het effect van ventilatie op de cognitieve prestaties van leerlingen op de basisschool, ("The effect of ventilation on the cognitive skills of primary school pupils"), Delft, TNO Bouw en Ondergrond, 2007.

Van der Schaaf, P. (2002). Public real estate, challenges for governments, Delft: DUP Science.

Wilkinson, S. J. \& Remøy H. (2011). "Sustainability and within use office building adaptations: A comparison of Dutch and Australian practices" in PRRES 2011 Conference Proceedings, Gold Coast Australia, Bond University. 